\title{
Peranan Desa Adat Intaran Dalam Pengelolaan Pantai Mertasari Kecamatan Denpasar Selatan
}

Ni Putu Ayu Anistya Dewi a,1, I Putu Anoma,2

1 anistyadewi2@gmail.com,2putuanom@unud.ac.id

a Program Studi S1 Destinasi Pariwisata, Fakultas Pariwisata,Universitas Udayana, Jl. Dr. R. Goris, Denpasar, Bali 80232 Indonesia

\section{Abstract}

Bali is one of the tourist destinations that is growing rapidly in Indonesia. Most people when they hear about bali island are synonymous with exotics beach. Bali is famous with the beautiful beach panorama. One of tourist attraction in the Bali Island is Mertasari Beach. Mertasari beach is an indigenous Intaran village. In tourism management is done one way to approach community institutions, namely the indigenous village institutions.

Intaran village is one of the indigenous villages that located in South Denpasar District. In terms of management in Mertasari Beach, Intaran village started to build a management in December 2014 by forming BUMDES (Owned Indigenous Village). However, management Mertasari Coast has not fully given to the village. In conducting the study authors used data collecting observation, interviews, documentation studies and literature studies with similar previous studies. These results indicate that the role of Indigenous Village in Beach Intaran in the management of Mertasari terms of existing management stage such as: Planning (Planning) covers, community empowerment programs, increase sustain ability in Mertasari Beach, improve hygiene in Mertasari Beach and financial planning. Organizing (Organizing) includes, forming management organizational structure is accompanied by a clear task. Mobilization of people (Actuating) include, mobilize communities in managing Mertasari Beach, and Supervision (Controlling) include, supervision in the field of employment, supervision in the field of security and supervision of the trader.

Keywords: Management, Role, Indigenous Village

\section{PENDAHULUAN}

Pariwisata saat ini sedang berkembang di Indonesia. Perkembangan pariwisata bisa dilihat dari banyaknya jumlah wisatawan yang berkunjung ke suatu daya tarik wisata, baik itu wisatawan domestik maupun wisatawan asing. Bali merupakan salah satu daerah tujuan wisata yang sangat berkembang pesat di Indonesia. Salah satu daya tarik wisata di Pulau Bali adalah Pantai Mertasari yang terletak di Kecamatan Denpasar Selatan. Pantai Mertasari memiliki daya tarik tersendiri, di Pantai Mertasari memiliki areal pantai berpasir putih yang cukup luas serta ombak yang cocok untuk olahraga layar.

Dalam pengelolaan pariwisata memerlukan pendekatan lembaga kemasyarakatan yaitu lembaga desa adat. Desa Adat Intaran merupakan salah satu desa adat yang berada di Kecamatan Denpasar Selatan. Pantai Mertasari merupakan palemahan Desa Adat Intaran. Dalam hal pengelolaan di Pantai Mertasari, Desa Adat Intaran mulai melakukan pengelolaan sejak bulan Desember tahun 2014, dengan membentuk BUMDES (Badan Usaha Milik Desa Adat). Tetapi, pengelolaan di Pantai Mertasari belum sepenuhnya diberikan kepada Desa Adat Intaran. Saat ini, Pantai Mertasari hanya bisa digunakan untuk kegiatan keagamaan seperti melasti dan hanya digunakan untuk berenang saja, tanpa ada daya tarik lainnya. Tetapi, kedepannya melalui KSPN (Kawasan Strategis Pariwisata Nasional) akan dilakukan penataan oleh Pemerintah Kota agar Pantai Mertasari menjadi destinasi unggulan, karena pada saat ini bantuan dari Pemerintah Kota hanya pengadaan parkir dan gazebo saja. Dengan kurangnya daya tarik di Pantai Mertasari, sehingga hal ini sangat memerlukan peranan desa adat dalam mengelola Pantai Mertasari agar nantinya menjadi destinasi yang dikenal oleh wisatawan asing maupun wisatawan domestik. Tujuan dari penelitian ini untuk mengetahui peranan Desa Adat Intaran dalam pengelolaan Pantai Mertasari.

\section{TINJAUAN PUSTAKA}

Tinjauan penelitian sebelumnya yang dijadikan referensi yaitu penelitian yang dilakukan oleh Tresna Dewi (2014) yang berjudul "Peranan Desa Adat dalam Pengembangan dan Pengelolaan Pantai Pandawa sebagai Kawasan Pariwisata di Desa Kutuh" dan penelitian terakhir dikutip dari Sucipta (2012) yang berjudul "Pengelolaan Pantai Kedonganan sebagai Daya Tarik Wisata Kuliner Berbasis Masyarakat di Desa Kedonganan". Adapun konsep yang digunakan dalam penelitian ini terdiri dari konsep peranan 
menurut Soekanto, Soejono, 2009 peranan merupakan aspek yang dinamis dari kududukan, tanpa adanya peranan dari tiaptiap individu, interaksi tidak akan pernah terjadi, sehingga masyarakat tidak akan terbentuk dan begitu seterusnya. Ditinjau dari tugas, maka ada dua macam peranan yaitu peranan aktif atau utama yaitu pelaku harus melakukan tugasnya pada saat dan tempat yang tepat. Tanpa adanya keaktifan itu, kegiatan yang dilaksanakan tidak berjalan dengan baik dan peranan pasif yaitu tanpa adanya campur tangan dari seseorang ataupun lembaga, kegiatan tersebut akan tetap berjalan.

Konsep pengelolaan menurut George R. Terry, 2006 berdasarkan fungsinya terdiri dari perencanaan (Planning), pengorganisasian (Organizing), penggerakan orang-orang (Actuating), pengawasan (Controlling).

\section{METODE PENELITIAN}

Ruang lingkup dalam penelitian ini yaitu keterlibatan atau peran aktif Desa Adat Intaran dalam pengelolaan Pantai Mertasari. Pengelolaan yang dimaksud adalah perencanaan, pengorganisasian, penggerakan orang-orang dan pengawasan yang dilakukan. Adapun sumber data yang digunakan dalam penelitian ini yaitu Data Primer yang diperoleh langsung dari pihak-pihak yang berkompeten, seperti Bendesa Adat Intaran, Sekretaris Desa Sanur Kauh dan Juru Parkir di Pantai Mertasari dan data sekunder berupa data yang diperoleh dari literatur, bahan bacaan yang ada kaitannya dengan penelitian ini, serta data yang diperoleh melalui browsing internet.

Teknik pengumpulan data yang digunakan dalam penelitian ini yaitu observasi, teknik ini menuntut adanya pengamatan secara langsung maupun tidak langsung terhadap objek penelitian. Wawancara, teknik wawancara dalam penelitian ini yaitu wawancara mendalam. Wawancara ini dilakukan dengan Bendesa Adat Intaran, Sekretaris Desa Sanur Kauh dan Juru Parkir Pantai Mertasari. Studi Dokumentasi, untuk melengkapi data yang diperoleh dan yang dibuat dalam penelitian ini, mengambil dokumentasi berupa foto-foto dan voice recorder guna merekam suara dari para informan saat melakukan wawancara secara langsung. Studi Kepustakaan, pengumpulan data yang dilakukan dengan mengambil beberapa penelitian sebelumnya dari beberapa laporan akhir/skripsi dan literatur yang ada kaitannya dengan penelitian ini. Teknik analisis data yang digunakan adalah teknik deskriptif kualitatif, dengan menguraikan dan memaparkan secara rinci data tentang peranan Desa Adat Intaran dalam pengelolaan Pantai Mertasari dengan menggunakan konsep pengelolaan.

\section{HASIL DAN PEMBAHASAN}

Desa Adat Intaran terletak di daerah Sanur Kauh, Kecamatan Denpasar Selatan. Salah satu daya tarik wisata di daerah Sanur Kauh yaitu Pantai Mertasari. Saat ini, Pantai Mertasari hanya bisa digunakan untuk kegiatan keagamaan seperti melasti dan hanya digunakan untuk berenang saja, tanpa ada daya tarik lainnya. Dengan kurangnya daya tarik di Pantai Mertasari, sehingga hal ini sangat memerlukan peranan desa adat dalam mengelola Pantai Mertasari agar nantinya menjadi destinasi yang banyak dikunjungi wisatawan. Adapun peranan Desa Adat Intaran dalam pengelolaan Pantai Mertasari adalah sebagai berikut :

\section{Peranan Desa Adat dalam Perencanaan (Planning)}

Perencanaan yang dimaksud yaitu pembuatan program oleh Bendesa Adat untuk meningkatkan kunjungan wisatawan ke Pantai Mertasari. Program-program dalam perencanaan meliputi :

1. Program pemberdayaan masyarakat.

Dalam hal ini, Desa Adat Intaran melakukan program pemberdayaan masyarakat, salah satunya dengan memberikan kesempatan kepada masyarakat untuk berjualan disekitar Pantai Mertasari. Saat ini sudah ada beberapa masyarakat yang berjualan di sekitar pantai, masyarakat yang berjualan di Pantai Mertasari tidak hanya masyarakat setempat saja, tetapi banyak masyarakat yang berasal dari luar berjualan di Pantai Mertasari. Dengan adanya peluang untuk berjualan di Pantai Mertasari, dapat meningkatkan penghasilan masyarakat sekitar.

2. Meningkatkan kelestarian di Pantai Mertasari

Dalam meningkatkan kelestarian di Pantai Mertasari, Desa Adat Intaran bekerjasama dengan masyarakat untuk ikut 
melestarikan Pantai Mertasari, baik itu sekaa jukung dan sekaa nelayan diwajibkan untuk ikut melestarikan Pantai

Mertasari. Selain itu, pelestarian di Pantai Mertasari juga dilakukan dengan penanaman bakau. Penanaman bakau ini diadakan di sebelah selatan areal Pantai Mertasari. Hal ini sering dilakukan oleh pihak-pihak pemerintahan, mahasiswa dan forum-forum lainnya. Dengan diadakannya penanaman bakau ini, dapat mengurangi abrasi air laut. Sehingga dengan kegiatan ini kelestarian Pantai Mertasari tetap terjaga.

3. Meningkatkan kebersihan di Pantai Mertasari

Kegiatan kebersihan di sekitar Pantai Mertasari sering dilakukan oleh Desa Adat Intaran. Kebersihan areal di Pantai Mertasari merupakan tanggung jawab bersama, baik itu juru parkir, pedagang, sekaa nelayan dan sekaa jukung. Maka untuk menjaga kebersihan di Pantai Mertasari diadakan kegiatan gotongroyong di areal pantai yang diadakan setiap sebulan sekali. Selain itu masyarakat di sekitar juga diwajibkan untuk ikut menjaga kebersihan Pantai Mertasari. Untuk meningkatkan kebersihan di sekitar Pantai Mertasari, disetiap sudutnya sudah disediakan tempat sampah, hal ini dilakukan agar wisatawan dan pengunjung tidak membuang sampah sembarangan. Selain itu juga terdapat himbauan untuk para pedagang sate, agar tidak membuang tusukan sate sembarangan di areal Pantai Mertasari. Kegiatan bersih-bersih di Pantai Mertasari juga sering dilakukan oleh forum-forum, baik itu mahasiswa maupun pemerintahan. Dengan meningkatkan kebersihan di Pantai Mertasari akan menimbulkan kesan yang baik bagi wisatawan yang berkunjung.

4. Perencanaan keuangan

Sumber dana di Pantai Mertasari diperoleh dari tarif parkir, penyewaan kano, penyewaan kios-kios pedagang dan penyewaan permandian. Di areal parkir pengunjung, tarif yang ditentukan yaitu Rp. 2000,- untuk kendaraan roda dua dan Rp. 3000,- untuk kendaraan roda empat. Pendapatan yang diterima setiap bulannya berasal dari penyewaan kano, parkir mobil, parkir sepeda motor, penyewaan toilet dan pemandian, dan dari penyewaan kios-kios pedagang. Selanjutnya dari pendapatan yang diterima setiap bulannya digunakan untuk membayar tenaga honor, membayar listrik pura, membayar listrik pemandian, PAM, digunakan untuk menyumbang ke Pura dan setoran ke desa. Dari pendapatan yang diterima, disetor ke desa sebesar Rp. 14.000.000,- perbulan. Sisa dari pengeluaran tersebut, setiap bulannya digunakan untuk membayar gaji juru parkir sebanyak tiga orang, juru parkir di Pantai Mertasari tidak mendapatkan gaji tetap. Setiap bulannya gaji yang didapatkan berbeda-beda, dari Rp. 1.600.000,00 - Rp. 1.900.000,00 per orang, tergantung dari sisa pengeluaran setiap bulan. Sampai saat ini, pendapatan di Pantai Mertasari masih dikelola oleh Desa Dinas.

\section{Peranan Desa Adat dalam Pengorganisasian (Organizing)}

Dalam pengorganisasian, Bendesa Adat belum memiliki struktur organisasi pengelolaan yang terpisah dengan struktur organisasi desa adat. Struktur organisasi Desa Adat Intaran dapat dilihat pada gambar 4.1.

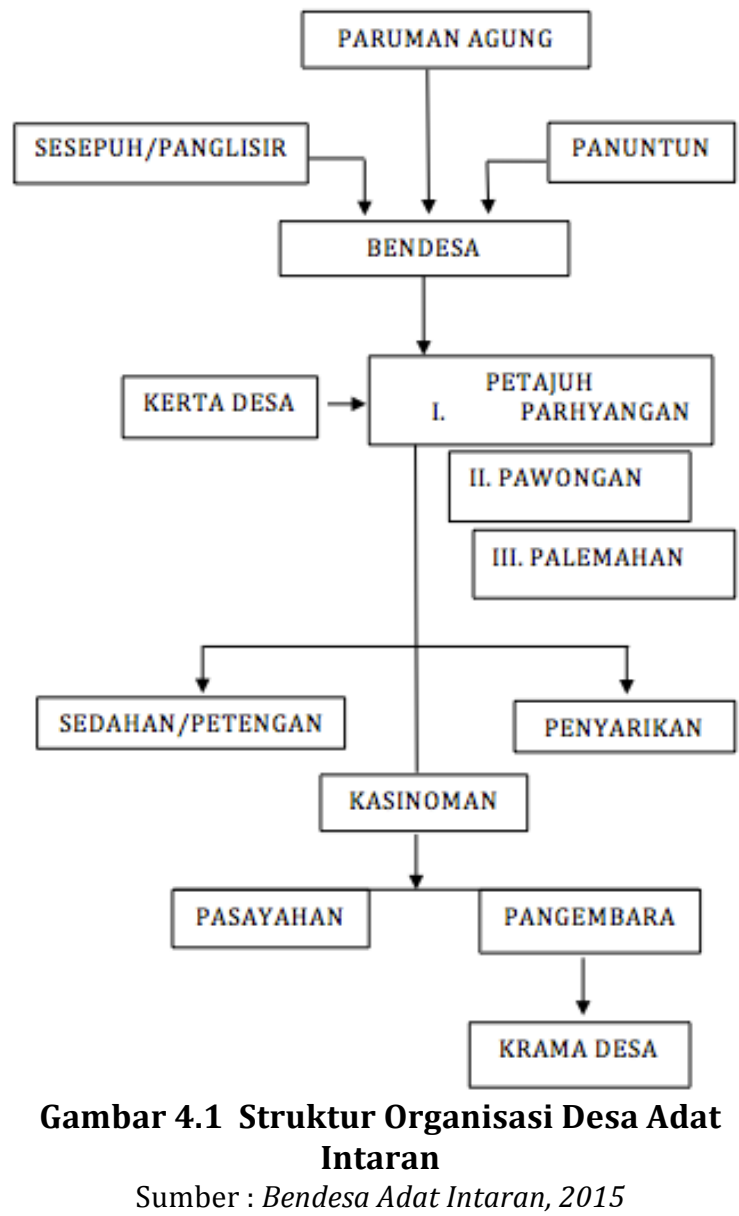


Adapun tugas masing-masing bagian dalam organisasi tersebut adalah sebagai berikut : Bendesa Adat memiliki tugas dan wewenang melaksanakan awig-awig desa adat, mengkoordinasikan tugas-tugas di Pantai Mertasari, Bendesa Adat berhak mengeluarkan keputusan demi keselamatan desa, Bendesa adat selalu mengambil keputusan berdasarkan awig-awig desa agar masyarakat tidak ada yang melanggar, Bendesa adat harus mengadakan catatan atau arsip tentang kelahiran, kematian, dan masyarakat yang keluar dari desa. Wakil Bendesa Adat memiliki tugas melaksanakan awig-awig desa adat, mewakili Bendesa Adat bila berhalangan hadir, membantu desa adat dalam melaksanakan tugas-tugasnya. Bendahara memiliki tugas membantu desa adat dibidang keuangan, bertanggung jawab atas semua pemasukan dan pengeluaran keuangan desa, melaporkan keadaan keuangan desa pada saat rapat. Sekretaris bertugas untuk mencatat keputusan hasil rapat dan membantu dalam hal pembuatan surat. Pecalang memiliki tanggung jawab terhadap keamanan desa dan Pantai Mertasari, dan selain itu masyarakat juga bertugas untuk melestarikan lingkungan disekitar Pantai Mertasari, dengan menjaga kebersihan yang ada di sekitar pantai, melakukan kerja bakti secara bergiliran dan ikut serta dalam menjaga keamanan Pantai Mertasari.

\section{Peranan Desa Adat dalam Penggerakan Orang-orang (Actuating)}

Peranan Desa Adat Intaran dalam menggerakkan orang-orang antara lain, pembagian tugas keamanan di lingkungan Pantai Mertasari dilakukan oleh pecalang secara bergantian. Dalam menjaga lingkungan di Pantai Mertasari, merupakan tangung jawab bersama. Juru parkir selain bertugas dalam pemungutan uang parkir, desa adat juga menugaskan untuk menjaga lingkungan di sekitar Pantai Mertasari. Selain itu para pedagang, sekaa jukung dan sekaa nelayan juga diwajibkan untuk ikut menjaga lingkungan di Pantai Mertasari baik itu dari kebersihan maupun kelestariannya. Masyarakat di sekitar Pantai Mertasari juga diwajibkan untuk menjaga kelestarian Pantai Mertasari, masyarakat biasanya ikut dalam program penanaman bakau dan tidak membuang sampah disekitar Pantai Mertasari. Untuk urusan pendapatan uang parkir dikelola oleh desa dinas. Pendapatan yang diterima setiap bulannya berasal dari penyewaan kano, parkir mobil, parkir sepeda motor, penyewaan toilet dan pemandian, dan dari penyewaan kios-kios pedagang. Selanjutnya dari pendapatan yang diterima setiap bulannya digunakan untuk membayar tenaga honor, membayar listrik pura, membayar listrik pemandian, PAM, digunakan untuk menyumbang ke Pura dan setoran ke desa. Sisa dari pengeluaran tersebut, setiap bulannya digunakan untuk membayar gaji juru parkir sebanyak tiga orang.

\section{Peranan Desa Adat dalam Pengawasan (Controlling)}

Peranan Desa Adat Intaran dalam pengawasan ini meliputi pengawasan dibidang tenaga kerja, pengawasan keuangan, pengawasan dibidang keamanan dan pengawasan terhadap pedagang. Adapun uraian lebih rinci dari pengawasan yang dilakukan adalah sebagai berikut :

1. Pengawasan pada bidang tenaga kerja Dalam pengawasan tenaga kerja, desa adat menetapkan aturan-aturan dalam bekerja. Dalam hal ini Desa Adat Intaran belum bisa merekrut tenaga kerja dalam jumlah yang banyak. Juru parkir selain bertugas memungut uang parkir di Pantai Mertasari juga diwajibkan untuk menjaga kebersihan dan menjaga lingkungan di areal Pantai Mertasari. Selain itu pecalang juga tidak hanya bertugas untuk menjaga keamanan, pecalang juga diwajibkan untuk ikut menjaga kebersihan di sekitar Pantai Mertasari.

2. Pengawasan dibidang keamanan Keamanan di Pantai Mertasari dilakukan oleh pecalang. Selain bertugas untuk menjaga keamanan dalam upacara keagamaan, pecalang juga ditugaskan untuk ikut menjaga keamanan di Pantai Mertasari. Selain itu untuk menjaga keamanan wisatawan saat berenang di Pantai Mertasari, di areal pantai diberikan tanda atau peringatan agar tidak berenang melewati batas tersebut.

3. Pengawasan terhadap pedagang

Dalam pengawasan ini, desa adat hanya memperbolehkan para pedagang untuk menjual makanan tradisional seperti sate, bulung, rujak, lumpia. Selain menjual makanan tradisional, di Pantai Mertasari juga terdapat beberapa kios yang menjual pakaian khas bali. Para pedagang 
tidak diperbolehkan untuk menjual minumanminuman keras. Selain itu agar tidak terjadi perselisihan antar pedagang, desa adat sudah membuat batas-batas untuk pedagang berjualan, sehingga para pedagang sudah mendapatkan tempat masing-masing untuk berjualan. Hal ini dilakukan untuk menghindari para pedagang liar untuk masuk sembarangan ke areal Pantai Mertasari dan menghindari adanya perselisihan antar pedagang.

\section{SIMPULAN DAN SARAN}

Berdasarkan hasil pembahasan tentang peranan Desa Adat Intaran dalam pengelolaan Pantai Mertasari, maka dapat diambil simpulan sebagai berikut, peranan Desa Adat Intaran dalam pengelolaan Pantai Mertasari belum optimal. Hal-hal yang dilakukan Desa Adat Intaran dalam pengelolaan di Pantai Mertasari yaitu Perencanaan (Planning) meliputi, program pemberdayaan masyarakat, meningkatkan kelestarian di Pantai Mertasari, meningkatkan kebersihan di Pantai Mertasari dan perencanaan keuangan. Dalam pengorganisasian (Orgazining) Desa Adat Intaran belum memiliki struktur organisasi pengelolaan yang terpisah dengan struktur organisasi desa adat. Penggerakan Orang-orang (Actuating) dengan menggerakkan masyarakat dalam mengelola Pantai Mertasari dan Pengawasan (Controlling) meliputi, pengawasan dibidang tenaga kerja, pengawasan dibidang keamanan dan pengawasan terhadap pedagang. Berdasarkan hasil pembahasan, maka saran yang dapat diambil yaitu untuk struktur organisasi, seharusnya Bendesa Adat membuat struktur organisasi pengelolaan yang terpisah dengan struktur organisasi desa adat. Sehingga dengan adanya struktur organisasi yang terpisah, pengelolaan Pantai Mertasari akan lebih professional, untuk pihak pengelola perlu mengadakan kerjasama dengan travel agent dan mengadakan promosi agar Pantai Mertasari lebih dikenal oleh wisatawan asing maupun wisatawan domestik. Saran yang selanjutnya ditujukan kepada pihak akademisi, perlu adanya penelitian mengenai strategi pengembangan Pantai Mertasari agar nantinya menjadi destinasi unggulan.
Daftar Pustaka:

Abdi Sucipta, Md. 2012. "Pengelolaan Pantai Kedonganan sebagai Daya Tarik Wisata Kuliner Berbasis Masyarakat di Desa Kedonganan".http://lpsdimataram.com/phocadow nload/Desember-2012/5-

pengelolaan $\% 20$ pantai $\% 20$ kedonganan $\% 20$ sebag ai $\% 20$ daya $\% 20$ tarik $\% 20 \% 20$ wisata $\% 20$ kuliner $\%$ 20berbasis $\% 20$ masyarakat $\% 20$ md.\%20abdi\%20sucipta.pdf (diakses tanggal 23 September 2016)

Haryanti, Ni Luh. 2009. "Peranan Desa Adat Kapal Dalam Pengelolaan Kawasan Pura Sada Sebagai Daya Tarik Wisata". Denpasar : Fakultas Pariwisata Universitas Udayana.

Noor, Juliansyah. 2011. Metodologi Penelitian. Jakarta : Penerbit Kencana.

R. Terry, George. 2006. Prinsip- Prinsip Manajemen. Jakarta : Bumi Aksara.

Soejono, Soekanto. 2009. Sosiologi Suatu Pengantar. Jakarta : Penerbit Rajawali Pers.

Tresna Dewi, Ni Luh Putu. 2014. "Peranan Desa Adat Dalam Pengembangan dan Pengelolaan Pantai Pandawa Sebagai Kawasan Pariwisata di Desa Kutuh".

http://ejournal.undiksha.ac.id/index.php/JJPP/arti cle/view/4544 ( diakses tanggal 23 September 2016) 